\section{Rediffusion and Teleprogramme Systems in Broadcasting}

$\mathrm{R}^{\mathrm{E}}$ DIFFUSION' is a method of distributing a broadcast programme over an independent line network to a number of subscribers. "Teleprogramme' is the method which enables a telephone subscriber, by means of a small amount of additional apparatus, to receive the ordinary radio broadcast programmes over his telephone network. The object of both systems is the same, namely, to reproduce the broadcast programme in the subscriber's home with the maximum fidelity ; but the means employed are quite different.

A good paper by Mr. A. R. A. Rendall and Mr. S. Van Vierlo discusses the two methods in Electrical Communication of October. Both methods are in use in various parts of the world. In rediffusion, the programme is usually received by radio; but it is better, when possible, to get direct reception from a studio. An amplifier station delivers the oscillations at such a level that all the subscriber needs to do is to bridge his loud speaker across the terminals. The sounds are then heard at the proper loudness, no adjustment being necessary. The choice of programmes is restricted, as although alternative programmes are easily provided, they add appreciably to the cost of the service. Recently designed systems offer a choice of four programmes. Considering this is all that is generally heard free from interference at an ordinary receiving set, this is satisfactory.

The success of the system depends a great deal on the position chosen for the amplifier station and the cables used for connecting it with the consumers. It should be near the centre of gravity of the load, and shielded cables should be used. In these undertakings, the maintenance of a high and uniform standard in the quality of the reception is essential if they are to compete successfully with receiving sets, the prices of which are being continually reduced. A partial failure or even periods of poor quality would seriously affect their prospects of success.

In a teleprogramme system, the radio broadcast is received on the subscriber's premises over his ordinary telephone network. This additional use of his telephone is sometimes a boon when it is not much used during the day and rarely in the evening. It is obviously a serious inconvenience to have the programme interrupted by a telephone call. Hence for subscribers with a high calling rate, an additional telephone cable is necessary to convey the programmes, and this adds to the expense. In most cases the subscriber has a choice between several programmes. By controlling a step-by-step selector at the telephone exchange, he is able to get the programme he wants. In this system it is necessary to limit the service to the normal speech level, and so an amplifier as well as a loud speaker has to be employed. In the rediffusion system this is not necessary as the transmission level is much higher. As the mere act of taking his receiver off the switch hook disconnects his amplifier, the subscriber can always use his telephone by interrupting the programme.

When considering the apparatus necessary for the supply of a group of 500 subscribers, it is customary to assume that not more than 60 per cent of them will be connected to a particular programme at the same time. In this case the amplifiers are usually rated for a power varying from 2 to 40 watts.

\section{University and Educational Intelligence}

Cambridge.-Mr. W. V. D. Hodge, University lecturer in mathematics, has been elected into a fellowship and appointed lecturer and director of mathematical studies at Pembroke College. Mr. Hodge was educated at George Watson's College, Edinburgh, the University of Edinburgh and St. John's College, Cambridge. He obtained a first class in Part 2 of the Mathematical Tripos in 1925 and was awarded a Smith's Prize in 1927. He also studied at Princeton University while holding a Senior 1851 Exhibition in 1926-31. He was on the staff of the University of Bristol and held a fellowship at St. John's College from 1930 until 1933.

Edinburgh.-The Cameron Prize for 1935 has been awarded to Prof. Julius Wagner-Jauregg, emeritus professor of psychiatry and neuropathology in the University of Vienna, in recognition of his discoveries regarding the malarial treatment of general paralysis.

LoNDon.-The following titles have been conferred in respect of posts held at schools of the University : professor of chemistry, Dr. J. W. Cook, the Cancer Hospital (Free); reader in organic chemistry, Dr. G. A. R. Kon, Imperial CollegeRoyal College of Science.

The William Julius Mickle fellowship for 1935 has been awarded to Dr. Solly Zuckerman.

The Carpenter Medal for 1934 has been awarded to Dr. R. J. Lythgoe.

Manchester.-Dr. A. H. Gibson, Beyer professor of engineering, has been appointed a pro-vicechancellor, for a period of two years as from January 23,1935 , on the resignation of Prof. Lapworth.

Dr. F. P. Burt, reader in stoichio-chemistry, has been elected dean of the Faculty of Science for two years from January 1935.

Dr. W. N. Bailey, senior lecturer in mathematics, has been appointed Richardson lecturer in pure mathematics.

The Research and Standardisation Committee of the Institution of Automobile Engineers has presented to the Engineering Department an experimental petrol engine, and Mr. Charles Day, of Messrs. Mirrlees, Bickerton and Day, Limited, has loaned a Ricardo Diesel engine complete with all testing equipment.

THE American adult educational enterprise known as "The University of the Air" is now entering upon its third year. Prof. John Dewey, addressing an audience of sixteen hundred on December 8 at New York City Hall on "Radio's Influence on the Mind", claimed for broadcasting that it is the most powerful instrument of social education the world has ever seen and one urgently needed to redress the balance between the modern means of exchange of physical things and those of knowledge and ideas. One of the most crucial problems of to-day is how to ensure the employment of this instrument for the social public interest, in preference to its use for propaganda designed to distort facts and mislead the public mind. The 1935 programme embraces talks on: education for a new social order, economic planning, psycho-analysis and studies in a museum. 
THAT biology should be taught in all schools to all pupils is one of the conclusions of the argument developed by Dr. C. J. Bond, Fernshaw, Springfield, Road, Leicester, in an address delivered to Section $L$ at the Aberdeen meeting of the British Association last year. The address is now obtainable in pamphlet form. Young people suffer to-day from no sound biological foundation having been laid during school life for, at any rate, three departments of life in civilised societies: (1) sex, marriage and parenthood, (2) eitizenship, (3) vocation. For (1) the foundation should include instruction in the general principles of genetics, including human heredity, with examples drawn from plant and animal life, and wise advice and guidance should be made available during school life and to young persons of both sexes who wish to marry. As regards citizenship, our present system of national education is marred by a lack of continuity and completeness answerable for the existence of a false conception in many minds of the real nature of individual liberty and of conflict of individual, social and racial interests. Vocational guidance is obviously more important for the welfare of the young citizen and prevention of waste of human capacity than examination of scholastic acquirements. It can only be given by skilled experts able to assess natural aptitudes and equipped with technical knowledge of the conditions and requirements of the diverse occupations open to 'school leavers', and this combination of psychological and technical knowledge must be acquired during and after the period spent in teacher training colleges by teachers specially interested in industrial life and vocational guidance. The address touches also on the steadily increasing ratio of old to young in the population, on biology and culture, on education in the right use of leisure and the limits of what can be achieved by education.

\section{Science News a Century Ago}

\section{The Linnean Society}

On February 3, 1835, at a meeting of the Linnean Society at which A. B. Lambert was in the chair, B. H. Hodgson, Dr. Kidd of Oxford and R, Garner, whose paper "On the Nervous Structure of Molluscous Animals" had lately been read, were elected fellows of the Society. The secretary read a paper by Mr. Bentham of the Horticultural Society "On the Various Species of the Genus Lotus, and the Allied Genera". The chairman exhibited the flowers and leaves of Dracona terminalis, a plant from the islands of the Pacific successfully cultivated at his own residence in Wiltshire. The flowers were used by the natives of the islands, he said, to flavour a liquid like beer, and the fibres of the long leaves served as threads. Profs. Bartoloni, Fries, Harlan, Harrold, Lichtenstein and Reinwardt, with Baron Delessert, were nominated to fill the vacancies in the list of foreign members.

\section{Meteorology at the Cape of Good Hope}

Writing from Edinburgh on February 5, 1835, to Sir John Herschel at the Cape, J. D. Forbes said : "I had a letter from Whewell the other day, communicating your obliging message to me about your very interesting meteorological results. ... The annual variation of mean pressure and also of hourly oscillation you mention is noticed by Humbolt in equatorial climates. Is the barometer highest in summer or winter? I fear we are likely to find little analogous to your observations at the Cape in the Mediterranean. The oscillation is undoubtedly greater : and I do not think the barometer is highest in bad weather. The variable pressure in different latitudes is a very important and to me, till lately, an unexpected fact. I hope that you will be able to bring your barometer safely home again, and so determine the height of your observatory. I hope you have your actinometer with you; here it has a sinecure, there being no sun worth measuring."

\section{Henry's Electrical Experiments}

On February 7, 1835, Prof. A. D. Bache wrote to the Committee of Publications of the Franklin Institute saying that "The American Philosophical Society, at their last stated meeting, authorised the following abstract of a verbal communication made to the Society by Professor Henry on the sixteenth of January last. A memoir on this subject has been since submitted to the Society containing an extension of the subject, the primary fact in relation to which was observed by Professor Henry as early as 1832, and announced by him in the American Journal of Science. Mr. Faraday having recently entered upon a similar train of observations, the immediate publication of the accompanying is important, that the prior claims of our fellow countryman may not be overlooked". Bache's letter was followed by an abstract from the report of the meeting of the American Philosophical Society which contained details of Henry's experiments with electric currents.

\section{Death of Baron Dupuytren}

On February 8, 1835, Baron Guillaume Dupuytren, the foremost surgeon in France, died in Paris. Born in humble circumstances at Pierre Buffière in Limousin on October 6,1777 , it is said that he was stolen when three by a lady of rank, but was afterwards recovered by his parents. Both in appearance and by his conversation he attracted the attention of people, and at the age of twelve years through the action of an army officer he was sent to the Collège de la Marche in Paris, and his youth was thus passed amidst the turmoil of the French Revolution. Subsisting on the most meagre of allowances, he was, however, able to study chemistry and anatomy and at the age of seventeen years, in 1794, obtained a post in the new School of Medicine founded under the direction of Fourcroy. From then his progress was unchecked. In 1803 he was made an assistant surgeon at the Hôtel-Dieu, in 1811 succeeded Sabatier in the professorship of operative surgery and in 1815 he was given the chair of clinical surgery, which he held until his death. He was also surgeon to Louis XVIII. "Haughty, austere, and brooking no rivals," says Seelig, "he trod through life always upwards, charming by his very disdain and constantly introducing technical innovations that have stood the test of time. By a queer twist of fate, one of the least significant of his accomplishments, a description of contracted palmar fascia, is the one to which his name has clung". The perseverance he had shown amid the difficulties of his early years was not more notable than the assiduity with which he always carried out his duties and the iron resolution which astonished all who came in contact with him. $\mathrm{He}$ was buried in the Père Lachaise cemetery, and a part of his large fortune was used for the founding of the Musée Dupuytren near the École de Médicine, Parjs. 